\title{
Through Arctic Eyes: Canada and Antarctica, 1945-62
}

\author{
PETER J. BECK ${ }^{1}$
}

\author{
(Received 11 July 1994; accepted in revised form 11 January 1995)
}

\begin{abstract}
This archival study investigates the nature and development of Canadian attitudes and policy towards Antarctica between 1945 and 1962. Throughout this period, the key continuity was the tendency to view Antarctic affairs from an arctic perspective. Canada, though becoming more preoccupied with the Arctic and avoiding active involvement in Antarctica, found it difficult to ignore the more remote and distant southern polar region. Although the Arctic and Antarctic are distinct regions in geographical, political, legal and other terms, they are both polar regions subject to a range of seemingly analogous controversies. As a result, certain post-1945 developments affecting Antarctica were deemed of potential relevance to its northern counterpart, thereby encouraging the Canadian government to consider the nature of its political, legal, scientific and other interests in Antarctica. Canada's efforts to remain on the sidelines were qualified by the fact that Antarctica was treated as a significant policy interest by other states - most notably, Australia, Britain and the United States-which not only kept the Canadian government well informed about developments but also asked frequently for its views. In 1959 the conclusion of the Antarctic Treaty forced the Canadian government to consider whether or not to accede to the treaty. In the event, the government, guided by a series of interdepartmental exchanges, decided against accession, which did not take place until 1988.
\end{abstract}

Key words: Antarctica, Arctic, Antarctic Treaty, United Nations, polar sovereignty, bipolar linkages, sector principle, International Geophysical Year (IGY)

RÉSUMÉ. Cette étude d'archives examine la nature et le développement des attitudes et des politiques canadiennes envers l'Antarctique entre 1945 et 1962. Durant toute cette période, l'élément clé de continuité a été la tendance à considérer les questions de l'Antarctique d'un point de vue arctique. Bien qu'étant de plus en plus préoccupé par l'Arctique et voulant éviter de s'impliquer activement dans l'Antarctique, le Canada trouvait difficile d'ignorer la région polaire australe plus éloignée et inaccessible. Quoique l'Arctique et l'Antarctique soient des régions distinctes du point de vue géographique, politique, juridique, ainsi qu'à d'autres égards, ce sont deux régions polaires sujettes à toute une gamme de controverses apparemment semblables. C'est pourquoi certains développements affectant l'Antarctique ont été jugés d'une importance potentielle pour son équivalent boréal, et ont encouragé le gouvernement canadien à examiner la nature de ses intérêts politiques, juridiques, scientifiques et autres dans l'Antarctique. La résistance du Canada à s'impliquer était conditionnelle au fait que l'Antarctique était vu comme un enjeu politique important par d'autres nations — en particulier l'Australie, la Grande-Bretagne et les États-Unis — qui, non seulement gardaient le gouvernement canadien bien informé des développements, mais lui demandaient aussi souvent son opinion. La signature du Traité sur l'Antarctique en 1959 força le gouvernement canadien à réfléchir à son adhésion éventuelle au traité. En fait, le gouvernement, guidé par une série d'échanges interministériels, décida alors de ne pas y adhérer et ne le fit qu'en 1988.

Mots clés: Antarctique, Arctique, Traité sur l'Antarctique, Nations unies, souveraineté polaire, liens bipolaires, théorie des secteurs, Année géophysique internationale (AGI)

Traduit pour la revue Arctic par Nésida Loyer.

\section{INTRODUCTION}

On 24 January 1950 Marcel Duranthon, the French consul general in Quebec, lectured on Antarctica to the International Relations Club at Laval University. Reginald Mitchell, the American consul in Quebec, found it a surprising choice of topic: "Insofar as this part of Canada is concerned the Antarctic is neither an important nor a timely subject. There would appear to be little, if any, interest here in this subject and there is not known to have been any previous public discussion of the subject here" (Mitchell, 1950). In many respects, Mitchell's observation was true for the rest of the country. The somewhat variable and spasmodic nature of government interest in the North during the interwar and immediate post-1945 periods failed to shake general perceptions of Canada's status as an arctic nation (DEA, 1985; Solem and Greenaway, 1989). Unsurprisingly, there existed little or no interest in what one official described as Canada's "Far South" (Lloyd, 1947). Canadian newspapers followed Antarctic developments in a pragmatic, inconsistent manner, as evidenced during August and September 1948 by stories carried in the Ottawa Morning Journal (19 August 1948), Montreal Gazette (21 September 1948) and Montreal Star (23 September 1948), while any press reports were notable for their absence of any reference to Canada's role and interests in Antarctica. Only the rare letter from a member of the public, expressing

${ }^{1}$ Faculty of Human Sciences, Kingston University, Penrhyn Road, Kingston upon Thames KT1 2EE, England

(C) The Arctic Institute of North America 
interest in the subject, was received by the government.

In spite of its wishes, the Canadian government was unable to insulate itself completely from the affairs of Antarctica, which attracted greater international interest and activity during the years following the Second World War. This period witnessed an increasingly serious controversy over ownership alongside the multilateral negotiations which culminated eventually in the signature of the 1959 Antarctic Treaty. Although Antarctica interested only a few countries and remained a relatively minor issue on the wider international stage during the late 1940s and the 1950s, the major players (Argentina, Australia, Britain, Chile, France, New Zealand, Norway, the United States and the Soviet Union) figured prominently in the broader calculations of Canadian policymakers, such as in matters touching upon relations with their powerful southern neighbour, Commonwealth loyalties, the Cold War, hemispheric and Latin American links, and bipolar interconnections. In addition, Ottawa was kept fully and regularly apprised of Antarctic developments by Canadian high commissions and diplomatic missions, most notably, those located in Buenos Aires, Canberra, London, Santiago, Washington and Wellington, as well as by Commonwealth, United States and other diplomats stationed in Ottawa. After 1945 Canadian membership of the British Polar Committee - this was dominated by Antarctic business-exerted a similar effect, as did discussions conducted at gatherings of Commonwealth prime ministers (e.g., October 1948). Canada, albeit technically an outsider, was given privileged access to confidential documentation and briefings about multilateral exchanges conducted on Antarctica. Even top secret working papers and memoranda were forwarded to Ottawa by the United States and Commonwealth governments.

Therefore, Canada was brought face-to-face with the Antarctic question on several occasions, and forced to consider the nature of its interests. During 1948, policymakers, discovering that "no policy has been established," sought to identify and clarify the nature of Canadian interests in Antarctica (Blanchette, 1948a). At an early stage of this process, Trevor Lloyd, chief of the Geographical Bureau at the Department of Mines, asserted that 'Canada's interests in the Antarctic regions are only indirect. They do, however, exist" (Lloyd, 1948). Department of External Affairs (DEA) memoranda drew heavily on Lloyd's initial listing, and on 30 July 1948 Lester Pearson codified the government's position (Pearson, 1948). Despite being prepared as a Cabinet paper, Pearson's memorandum was never actually brought before the Cabinet, but was formally approved on 3 August by L.S. St. Laurent, the Minister of External Affairs.

Naturally, the Arctic remained the prime polar focus for Canadian policymakers (Pearson, 1945-46; Grant, 1988), as highlighted in 1948 by the creation of the Advisory Committee on Northern Development (ACND) to plan and coordinate northern activities (Rowley, 1992). But, after 1945, the simultaneous, ongoing and emerging nature of the Arctic and Antarctic questions, including their focus upon a seemingly similar range of political, legal, scientific and other concerns, rendered it difficult to avoid drawing analogies between the two polar regions (Marsden, 1966). Frequent official use of the word "indirect" to describe national interests in Antarctica failed to obscure the reality that Canada was not totally disinterested in the course of events therein. This paper considers the nature and development of Canadian interests in Antarctica between 1945 and 1962. The close of this period witnessed the conclusion of the 1959 Antarctic Treaty, which became effective in June 1961, thereby transforming the vast southern continent into a zone of peace, a continent for science, and a special conservation area (Beck, 1992).

\section{LEGAL INTERESTS}

Despite the uncertain and evolving nature of international law (e.g., requirements for "effective occupation" in sparsely populated areas, validity of the sector principle), during the 1920 s and 1930s successive governments expressed confidence in the strength of Canadian sovereignty in the Arctic (Cory, 1936). Indeed, by the late 1940s the sovereignty problem was adjudged to be largely settled, particularly as compared to its southern counterpart, where varying answers were offered still to the question "Who owns Antarctica?" (Beck, 1994). Thus, in March 1948 Arthur Blanchette discussed the escalation of the Argentine-British-Chilean dispute:

Conflicting territorial claims in the Antarctic have become somewhat of a fixture after decades of concentrated international exploration there and the recent ArgentineChilean expeditions, which served to set off the current dispute, are but the latest symptoms of a malaise which is becoming more commonly known as Antarcticitis (Blanchette, 1948b).

Within Ottawa, these developments were studied closely for guidance on principles influencing polar sovereignty in general and in the Arctic in particular, as acknowledged by Hume Wrong, the Canadian ambassador in Washington (Wrong, 1946).

By the 1930s, Australia, Britain and New Zealand claimed over $60 \%$ of Antarctica. Membership of the Committee on Polar Questions enabled Canada to follow discussions conducted at the 1937 Imperial Conference about a possible challenge to the enclave (Adélie Land) claimed by France within Australian Antarctic Territory (AAT). The eventual decision to acquiesce in the French claim was welcomed by Canada's representatives, who deprecated "any denial of the sector principle in Adélie Land" because of possible "embarrassing repercussions in the Arctic" (Imperial Conference, 1937). Indeed, Fitzmaurice, the Foreign Office's legal adviser, minuted that only Australia and Canada displayed much interest in the subject (Fitzmaurice, 1937).

Wartime events, most notably, the initiation of a permanent British presence through bases established by "Operation Tabarin" (Beck, 1987), resulted in a significant upgrading of official perceptions regarding the criteria required for 
'effective occupation' in Antarctica. In Canada, these developments, in conjunction with what has been described as the wartime northern "sovereignty crisis" (Grant, 1988:129), prompted a renewed focus upon its position in the Arctic (Bériault, 1942; Chaput, 1944). The DEA, viewing its rights as "unchallenged but not unchallengeable" (Holmes, 1979: 172), acknowledged that "requirements of effective possession are now greater, and necessity of continuity of effective possession is now emerging almost as a new requirement of international law" (DEA, 1945).

Events during the post-1945 period further clarified the situation in polar areas. Moves towards a more permanent scientific presence in Antarctica proved influential, even if legal uncertainties persisted, especially as the United States refused to recognize the effectiveness of existing claims. Canadian thinking was guided also by the views of international lawyers, particularly those of the Foreign Office's legal advisers forwarded through the high commission in London (Molson, 1948). There was also case law; thus, in 1954 the Anglo-French Minquiers and Ecrehos case led the British government to conclude that insufficient action had been taken against Argentine-Chilean infringements of British sovereignty over its Antarctic territories described as the Falkland Islands Dependencies. In turn, other Commonwealth states, including Canada, were advised about the legal risks of acquiescence in any act liable to be regarded by a rival as implying sovereignty over disputed polar territory (Commonwealth Relations Office, 1954). Within this context, it became increasingly clear that the sector principle was being pushed aside by the principle of effective occupation.

During both the late 1940s and early 1950s the British government, searching for a way out of the impasse, proposed referral of the Anglo-Argentine-Chilean dispute to the International Court. The Canadian government, having been consulted, stressed Britain's freedom of action, even if, in private, the DEA and Department of Northern Affairs proved more sympathetic towards the British position. Support for a peaceful settlement was accompanied by a desire for an authoritative opinion by the International Court: "From the purely Canadian point of view ... our personal interest (lies) in a judicial determination of the weight to be given to sector claims in international law within the context of the now accepted principle of effective occupation" (Parry, 1954). In the event, Argentine and Chilean opposition foiled this hope.

In addition, Soviet legal publications, reflecting the post1945 escalation of the USSR's activities in Antarctica, attracted close scrutiny in Canada. Soviet commentators, responding predictably to Cold War and ideological considerations, criticized Antarctic claims advanced by "imperialist" states in support of "aggressive" western interests (Afonin, 1948; Leontiev, 1950; Kostritsyn, 1951:43). During 1951 Kostritsyn's "Regarding the Question of the Regime of the Antarctic" was analyzed carefully in Canada (Canadian Embassy, Moscow, 1951), given his emphasis on both the "immense difference between the northern and southern polar regions" and the continued validity of the sector principle in the former: "The theory of sectors in the Arctic can be justified historically, economically, and strategically" (Kostritsyn, 1951:38-39).

In the past, occasional difficulties about the Arctic had arisen between Ottawa and Washington, as demonstrated by Canadian irritation about the continuing refusal of United States nationals to seek permission for entry to its northern territories. As a result, Canadian policymakers kept a close watch on the northern implications of the United States's position towards Antarctica: their concern was reinforced by Washington's refusal either to subscribe to the sector principle or to recognize existing claims. Certainly, the United States government saw links between the two polar regions; for instance, a 1952 position paper acknowledged that "any solution of the [Antarctic] territorial problem should not constitute a precedent adversely affecting US interests in the Arctic" (U.S. Government, 1952). Reports about United States' activities at both poles fostered a sense of caution on the part of Canadian policymakers:

There is the danger of an analogy being drawn in the Arctic; the United States might be encouraged to believe that just as it is being called into the Antarctic to ensure positions for New Zealand, Australia and the United Kingdom, which they cannot maintain alone, so in the Canadian North where its participation in our defence programme is extensive, it is sharing our legal rights ... We would prefer an arrangement that would cast no shadow, however faint, on our exclusive sovereignty in the Arctic (Léger, 1957).

Professor J. Tuzo Wilson, speaking to Canadian diplomats in New Zealand upon his return from Antarctica, confessed to being "both impressed and disturbed" by the magnitude of the American effort therein during the International Geophysical Year (IGY: 1957-58). Wilson, who was based at the University of Toronto, pointed to the "grave implications for Canada's sovereignty":
Until recently, the Canadians could rightly claim to be the experts on the Arctic and, on the basis of prior exploration and discovery, could defend their territorial claims to the Arctic islands ... Now, however, the situation has changed. Owing to the preponderant amount of information on polar conditions which the Americans have acquired, the United States government has earned the right, in Dr. Wilson's view, to contest the very premise upon which the Canadian claims to sovereignty in the Arctic Archipelago is based (Wilson, 1958).

Even allowing for his vested interest in enhancing the level of northern research, Wilson's report highlighted bipolar interconnections alongside science's role as the currency of polar law and politics.

Throughout this period, there was little or no Canadian interest in Antarctica per se. Canada's prime concern arose from an awareness of the ramifications for Canadian sovereignty in the Arctic, even if Antarctic developments were 
merely one of several external influences upon Canadian thinking about the Arctic. Other influences included international legal judgements (e.g., Anglo-Norwegian Fisheries and the Minquiers and Ecrehos cases of 1951 and 1954) and agreements (e.g., the Territorial Sea Convention, 1958) (Killas, 1987; Pharand, 1988).

\section{SCIENTIFIC AND TECHNICAL INTERESTS}

For Canada, arctic research, though helping to satisfy the activity criterion required for effective occupation, provided knowledge and understanding. Also, it raised questions about the merits of circumpolar and bipolar research strategies. For example, how far could Antarctic research yield information relevant to an understanding of the Arctic in general as well as to scientific problems of specific importance to Canada in such spheres as cartography, geology, gravitational studies, magnetism, meteorology, and radio transmission? Was there scope for technical and logistical cooperation in polar regions? Was expertise transferable from one pole to the other, as suggested by the United States' use of the less politically sensitive Antarctica for cold-weather training and equipment "under Arctic conditions" (Beck, 1986:37)?

During the 1940s and 1950s, Canada undertook only a marginal scientific Antarctic involvement. Few resources were available for Antarctica. Limited funds and equipment, in conjunction with the higher costs and politico-legal risks of Antarctic expeditions, resulted in a concentration on the Arctic. Nevertheless, Canadian scientists attended relevant conferences (such as the Antarctic Meteorological Symposium, Buenos Aires, 1959), monitored Antarctic research, and requested information about a wide range of projects, like a French automatic weather station in Adélie Land (February 1957) and the Soviet use of rockets for meteorological purposes (December 1957).

At the same time, there were repeated requests from countries active in Antarctica (e.g., Argentina, Australia, and Britain) seeking to utilize Canadian polar expertise, technology, and equipment. For instance, a Canadian ice-boring machine was used by the 1949-52 Norwegian-British-Swedish expedition (Giaever, 1954), Canadian-built aircraft supported Australian and New Zealand scientists in the 1950s, while during 1949-51 a Norseman plane piloted by Peter Borden St. Louis, a Canadian, undertook a photographic reconnaissance of part of the Falkland Island Dependencies for the British government. Miles Clifford, the Falklands Governor, visited Ottawa to make the arrangements, and subsequently reported on St. Louis' "good work" in the face of "unpredictable weather and undependable charts" (Clifford, 1950). Thus, the St. Louis example, albeit overlooked by Dean Beeby (1994), highlights the fact that Canadian participation in Antarctica occurred largely on an individual, often unofficial, basis, even if it often resulted in distinguished, even heroic and pioneering, contributions to Antarctic exploration and research (Hattersley-Smith, 1986; Roots, 1987; Beck, 1990; Beeby, 1994).
Career histories suggest an interesting two-way process: Antarctic work, building upon pre-existing northern experience, provided information and expertise beneficial for the Arctic. For example, Andrew Taylor (1907-93), the first Canadian ever to lead an Antarctic expedition (Operation Tabarin, 1944-45), utilized this experience subsequently in work on the Arctic weather station at Resolute, the siting phase of the Distant Early Warning (DEW) line, and on the Snow, Ice and Permafrost Sub-Committee of the Building Research Council of Canada (Taylor, 1947; Beeby, 1994; Davies, 1994). There is also the case of Fred Roots, who has proved a major force in Canadian polar, circumpolar and bipolar activities. Roots, a native of British Colombia, was even refused permission by the Geological Survey of Canada to join the 1949-52 Norwegian-British-Swedish expedition as chief geologist because of its perceived "irrelevance" to the Survey's work (E.F. Roots, pers. comm. 1989; T. Lloyd, pers. comm. 1989). As a result, he was forced to resign from the Geological Survey (Beeby, 1994) and to seek another post (eventually, he joined the Polar Continental Shelf Project) on his return from an expedition in which his contribution was commemorated by "Rootshorga" (Roots Knoll) in Queen Maud Land.

\section{Canada, the International Geophysical Year and the Trans-Antarctic Expedition}

Despite its worldwide character, the International Geophysical Year (IGY) of 1957-58 included a significant Antarctic component. Norway, the United States, and the Soviet Union were not only active at both poles but also diverting scientific and other resources to the far south ( $\mathrm{T}$. Lloyd, pers. comm. 1989). By contrast, Canadian participation in the IGY took place entirely on its own soil, as rationalized by Dr. D.C. Rose, chairman of the Canadian Committee for the IGY: "Since our own territories are so extensive that they will take all our efforts, we are not sending expeditions to other countries" (Rose, 1957).

In the event, repeated British requests for Canada's views, in conjunction with attendance at meetings of the Polar Committee and the "old Commonwealth countries" in London, familiarized Canada with IGY issues in general and with proposals for a Commonwealth Trans-Antarctic Expedition (TAE) led by Fuchs and Hillary in particular. Despite anticipating a negative response, the British government sought Canada's views about participation in the TAE. Unsurprisingly, interdepartmental exchanges displayed minimal interest, indicating that the country's interest in ice and snow could be fully satisfied in the Arctic. A negative reply was forwarded to London in September 1954 (Côté, 1954a), although Côté had warned the British High Commission at Ottawa already that, "even for Commonwealth solidarity ... we would not trudge the wastes of Antarctica" (Côté, 1954b). Nevertheless, the TAE was able to use Canadian expertise (e.g., the Spartan Air Company for aerial photography) and equipment on the usual unofficial, commercial basis (Montreal Star, 22 October 1955), even if, at one stage, a British 
request for RCAF support caused initial disquiet (DEA, 1955a).

Looking back, the IGY episode proved a significant longterm influence in Antarctica. It established the value of polar research conducted through international scientific cooperation, while providing a strong basis for the secret negotiations (1958-59) responsible for the 1959 Antarctic Treaty; thus, the initial twelve signatories were all active in Antarctica during the IGY. Although it prompted no change of direction in Canadian policy towards Antarctica, the IGY was not entirely without influence; it highlighted the merits of both polar research and bipolar links, as acknowledged by Professor J. Tuzo Wilson, who had recently visited Antarctica: "If there is one thing that the IGY has brought out it is that we don't know enough about the Polar regions" (Toronto Telegram, 7 January 1959).

\section{POLITICAL INTERESTS}

Geographical, legal and strategic reasons help to explain the Canadian preoccupation with the Arctic (Grant, 1988). Even so, policymakers in Ottawa found it difficult to ignore the global political ramifications of the Antarctic question; thus, the Cold War context fostered an understandable desire for peace, stability and harmonious relationships among states active in Antarctica.

Nor was Canada allowed to ignore Antarctica. Despite acknowledging the indirect nature of Canadian interests, Australia, Britain, and New Zealand kept Ottawa informed of developments, while sounding out the government's views on specific proposals. For Canadian high commissioners in Canberra, Wellington, and, to a lesser extent, London, Antarctica proved one of the more frequent topics for conversation with their respective host governments. Similarly, the subject was often raised by ministerial visitors to Ottawa. For example, during September 1955 Lester Pearson, the Canadian Minister of External Affairs, received Richard Casey, his Australian counterpart, who was en route to the United States: "Somewhat to my surprise, Casey said that this [Antarctica] was one of the most important subjects of discussion which he proposed to bring up when he reached Washington" (DEA, 1955b). On a further visit in September 1959, Casey commented again at length on Antarctica, alongside other topics like the Colombo Plan, New Guinea, and West Germany (DEA, 1959a). Antarctica was a regular topic for pre-1939 Imperial Conferences $(1921,1926,1930,1937)$ and post-1945 Commonwealth prime ministers' conferences (e.g., October 1948). Like other dominions, Canada was represented on the British government's Polar Committee, which examined "questions of policy in the Antarctic, taking into account also the bearing on these questions of policy in the Arctic" (Dominions Office, 1945). The Polar Committee, though receiving the Canadian Arctic Research Advisory Committee's annual reports on recent activities in the Canadian Arctic, concentrated on Antarctic affairs. Few meetings proved of real interest to Canada.
There was also the American dimension. The United States' growing role in Antarctica, including its refusal to recognize existing territorial claims, preoccupied Britain and other Commonwealth states. However, at the same time, the Cold War explained the aim shared by the United States, Commonwealth and Latin American governments to exclude the Soviet Union from Antarctica. This objective was treated sympathetically in Canada, which supported efforts tolimit the USSR's "political mischief-making" in Antarctica (DEA, 1958).

For most of the late 1940s and 1950s, Antarctica was covered by the DEA's Latin American desk; this reflected not only its location below the tip of the American continent but also the topic's perceived significance for Canada's relations with Latin American states in general and with Argentina and Chile in particular. The latter countries, attaching high priority to their respective overlapping Antarctic claims, challenged British sovereignty, thereby giving rise to an "Antarctic Cold War" (Ottawa Citizen, 13 February 1954). The Canadian government, though often offering implicit support for the British position in private, assumed a neutral attitude of avoiding public pronouncements regarding the merits of any claim. Canada, advocating western unity at a time of serious East-West tension, regretted the Anglo-ArgentineChilean dispute, including its apparent escalation during the early 1950s. The most serious clash occurred in 1952, when Argentine troops fired shots over the heads of British scientists who were attempting to re-establish the base station at Hope Bay (Beck, 1986). Canadian worries were accentuated in 1953, when the government was forewarned of Britain's intention to remove Argentine and Chilean "intruders" from Deception Island, Falkland Islands Dependencies (Pearson, 1953). Undeterred by Canadian warnings about adverse impacts throughout Latin America, the British government went ahead, as reported by the Ottawa Citizen (21 February 1953): "British toss Argentina off Island." In the event, the DEA, having requested urgent reports from its diplomatic missions about reactions, was relieved to hear that the general response in Latin America, even on the part of Argentina's government-controlled press, was relatively muted.

The United Nations' prominent role in Canadian foreign policy objectives resulted in the expression of hopes that any internationalisation arrangements for Antarctica should take full account of the UN dimension. By contrast, the Australian, Argentinian, British, Chilean, South African, and United States governments, fearing that this approach would open the door to unwelcome Soviet interference, opposed any substantial UN involvement in Antarctica. Cold War considerations, alongside the USSR's possession of a permanent seat on the Security Council, coloured a South African comment that attracted attention in Ottawa:

It may open up prospects of similar action in the north polar regions and North Pole itself and raise issues of far-reaching importance for the future security of the west. Both north and south polar regions should be kept out of the reach of the Security Council as at present constituted (South African DEA, 1948). 
Within the DEA, Blanchette, reading a British note, wrote "Arctic" in the margin alongside a passage arguing that "a dangerous precedent might be created which would have implications for other parts of the Empire which are inhabited or sparsely inhabited" (Blanchette, 1948c).

Lester Pearson counselled caution:

The cases are not, of course, parallel, and any attempt to treat them as such should be vigorously resisted ... The possibility, moreover, that any international organization for the Antarctic might be exploited to our disadvantage as regards the Arctic, makes it advisable for us to take no active role in the settlement of the Antarctic dispute (Pearson, 1948).

Nevertheless, Pearson departed from this brief in September 1955, when he horrified his Australian counterpart by expounding the benefits of UN intervention in Antarctica. Casey, whose government faced growing Soviet activity within the Australian Antarctic Territory, retorted by asking how Canada would feel about similar action in the Arctic. Pearson, who later admitted speaking "somewhat imprudently," replied that "we could not very well propose anything for one end of the globe that we were not willing to accept for the other, where our interests were involved" (Pearson, 1955).

In fact, the issue really came to the fore during 1956, and to a lesser extent during 1958-59, when India attempted to place "the question of Antarctica" on the UN's agenda (Statesman, India, 20 February 1956), much to the surprise and consternation of the governments active in Antarctic affairs. Once again, attendance at regular discussions held in London and at UN headquarters in New York by the "old Commonwealth" countries qualified Canadian efforts to remain on the sidelines. Within the DEA, contradictory thoughts emerged on the subject. On the one hand, there were general policy reasons to back the Indian proposal, such as those relating to support for internationalising Antarctica through the UN or to the fact that alignment with a leading Asian power would make the UN look less a "western club." On the other hand, the proposal was resisted strongly by friendly governments active in the region. International cooperation, they argued, was already working effectively in the region, thereby obviating any need for UN participation. Also, there were the usual Arctic implications, which were now extended to embrace self-determination.

Discussions in the United Nations might give rise to incidental discussion of the Arctic. Because we should presumably wish to safeguard Canadian sovereignty in the Arctic Archipelago and would wish to discourage discussion of the status of Eskimos, it might be necessary to emphasize that there is no geographical or political analogy between the Arctic and the Antarctic (Cadieux, 1956).

From an early stage, other Commonwealth governments acknowledged what one Australian diplomat described as the DEA's "cleavage of opinion" on the subject (Australian High
Commission, Ottawa, 1956). At one time, Australian diplomats feared a serious disagreement with Canada on the matter (Pyman, 1956), but in October 1956 the Canadian government informed India of its view that UN intervention would merely aggravate an already complex problem (Australian High Commission, Delhi, 1956). In the event, the problem went away. The Indian government, responding to strong lobbying and reassurances about the continued "peaceful utility" of Antarctica, withdrew the item, especially as more urgent international problems (i.e., the Suez and Hungarian crises) came to occupy centre stage. Similarly, during 1958-59, when India renewed the UN proposal, the initiative was overtaken by the concluding stages of the Antarctic Treaty negotiations.

\section{OTHER INTERESTS}

During the 1940s and 1950s discussions by Canadian policymakers about Antarctica were notable for their omission of any reference to economic factors. Although this feature might be excused on the grounds of the "indirect" nature of Canada's interests, there was a clear failure to acknowledge the actual economic and fiscal benefits arising from the use made by other countries of Canadian expertise and equipment in Antarctica, as outlined above. In fact, this tendency continues today, at a time when "perhaps Canada makes a greater financial return from activities performed in Antarctica than any other country" (Beck, 1990:19).

Nor were environmental factors influential during the decade or so after 1945. Conservation, which had yet to become a major international concern, was mentioned only briefly in the Antarctic Treaty (Article $\mathrm{IX}_{\mathrm{If}}$ ). Nevertheless, DEA evaluations specifically noted, without elaborating, the treaty's focus on "the preservation of wild life and fisheries resources" and "provision for the preservation and conservation of living resources in the Antarctic" (Hardy, 1959a).

\section{THE ANTARCTIC TREATY: NEGOTIATION, SIGNATURE AND RATIFICATION}

During the late 1950s the Canadian government, informed by confidential documentation passed on by Commonwealth governments as well as personal contacts (G. Rowley, pers. comm. 1989), watched the Antarctic treaty negotiations closely. There was, of course, no question of either participation in the talks or signature of the actual treaty. The Canadian government merely sent a representative to attend the opening public plenary session of the conference held at Washington in October 1959 to finalize the agreement.

Nevertheless, the negotiations prompted a detailed reevaluation of the government's position towards Antarctica. In many respects, the prime concern was to protect special interests, as noted in June 1959 by Hardy:

Canada has certain negative interests in the matter. Generally speaking, we do not wish broad principles to be 
enunciated which might be applied to both polar areas. We do not, for example, wish any country to argue successfully that polar areas are properly international areas over which no one country or group of countries should expect to maintain effective legal sovereignty, or that polar areas, because of their frigid characteristics, cannot be considered as coming within accepted concepts of sovereignty. We are interested in the definition of the continent and its surrounding seas, the preservation of the wild life and fisheries resources, the exchange of scientific ideas and information, and the impact which the conference possibly might have on Canada's position at the forthcoming conference on the law of the sea. We are also, I suppose, desirous of staying out of an argument in which so many of our friends and allies are involved. None of these interests would appear to be threatened at the present time (Hardy, 1959b).

Although this statement largely codified long-standing concerns, there were newer preoccupations, such as those related to the recently initiated law of the sea discussions.

In December 1959 the signature of the "historic ... Polar Peace Treaty" (Ottawa Citizen, 1 December 1959) rated front page coverage in several Canadian newspapers, which frequently quoted President Eisenhower's interpretation of the treaty as "a significant advance towards the goal of a peaceful world" (Toronto Globe and Mail, 2 December 1959). According to DEA appraisals, the Antarctic Treaty's useful and noteworthy points included the protection of polar sovereignty claims; the participation of major powers; the ban on nuclear explosions; provisions for demilitarization and inspection; the prospects for reduced friction in Antarctica; and references to the United Nations (i.e., in the preamble, articles $\left.\mathrm{III}_{2}, \mathrm{X}, \mathrm{XIII}_{1,6}\right)$ (DEA, 1959b). Canada's global perspective meant that interest was taken in the view, as articulated by one New Zealand diplomat present at the Washington conference, that the treaty represented proof of the "melting" of the Cold War (Hardy, 1959a). Indeed, the recent EisenhowerKhrushchev summit meeting held at Camp David (September 1959) encouraged the view that the treaty represented not only the "Camp David spirit" in action but also "a notable step towards international cooperation in the field of disarmament and the control of nuclear energy" (Hardy, 1959a). Significantly, NATO (North Atlantic Treaty Organization) took note of the Antarctic Treaty at its Council session held on 9 December 1959. Against this background, the DEA monthly bulletin's coverage concentrated on the broader aspect: "The tolerance and willingness to compromise displayed throughout the negotiations has provided hope that similar progress can be made in other areas of international discord" (DEA, 1960:515; Preston, 1965). Of course, for Canada, these "other areas" excluded the Arctic. Perennial northern sensitivities, reinforced by continuing press debates about "Whose Arctic is it?" (Toronto Telegraph, 25 April 1959), explained why the DEA's monthly bulletin referred deliberately to "problems peculiar to the Antarctic" in its article on the treaty talks (DEA, 1959c:350).
In Ottawa, the Antarctic Treaty's legal implications were examined in more detail, with specific reference to the Arctic: "From Canada's point of view the treaty successfully avoids any questioning of sovereignty in polar areas ... [and] solves a dispute in which many of our closest friends and allies were involved" (Hardy, 1959a). In fact, it is more correct to state that the Antarctic legal problem was shelved, not "solved," since article IV of the Antarctic Treaty merely involved an agreement to disagree. The DEA noted with interest that the treaty was defined to cover "islands," "territory" as far as the ice shelves, and the overlying air space, but specifically excluded the high seas. Accession arrangements, it was felt, reflected considerations related to the cold war (i.e., the desire of western powers to exclude Communist China and East Germany from Antarctic affairs) and the law of the sea discussions (i.e., accession by any state invited by the United Nations).

Subsequently, the Canadian government kept a watching brief over developments. Certainly, there existed a desire to remain reasonably well informed about Antarctic affairs and meetings conducted by Antarctic Treaty parties. High commissions and embassies were instructed to pass on relevant information, a process helped by the continued willingness of Australia, Britain, New Zealand and the United States, among others, to meet Canadian requests. Further news was furnished on an occasional basis by Canadians working in Antarctica, such as for Argentina, Chile and the United States (e.g., Ottawa Journal, 18 October 1961; New York Times, 13 November 1961). Also, in 1960, the DEA, prompted by a New Zealand suggestion, considered the merits of dispatching an official to ascertain "on the ground" the impact of the Antarctic Treaty (High Commission, Wellington, 1960). Eventually, the DEA authorised Edmonds, a diplomat based at the high commission in Wellington, to undertake the visit, but instructed him to be careful when discussing Canada's position towards both the Antarctic Treaty and polar sovereignty claims because "these may carry implications for Canada's Arctic claim" (DEA, 1961).

Edmonds' trip south, reputed to be the first ever by a Canadian diplomat, occurred between 3-11 November 1961 with the help of travel arranged locally in New Zealand. The tour was adjudged successful from both the representational and informational points of view; thus, Edmonds met Admiral Tyree (United States Antarctic Projects Officer), visited the South Pole, and was interviewed at McMurdo base for Canadian Broadcasting Corporation radio (High Commission, Wellington, 1961, 1962a). Upon his return, Edmonds sent the DEA lengthy papers on international cooperation in Antarctica and the US Antarctic programme. He reported the "striking" degree of international cooperation in the region, the US-USSR scientist exchange programme, and the respect for non-militarization provisions highlighted by the blocked gun emplacements on USN ships and the USN's prohibition of salutes and carrying arms within the Antarctic Treaty area (High Commission, Wellington, 1962b). Edmonds reminded the DEA that the country's historic links with Antarctica were recorded by “Canada Glacier" (located at $77^{\circ} 37^{\prime} \mathrm{S}, 162^{\circ} 50^{\prime} \mathrm{E}$ ), 
which was "one of the most beautiful glaciers" in the Dry Valley region (Edmonds, 1962). Edmonds also wrote an article for the DEA bulletin (DEA, 1962a). Naturally, the DEA ensured that his text, avoiding political and legal complications, concentrated on less sensitive aspects, like J.T. Wilson's 1958 visit, the use of Canadian equipment in Antarctica (e.g., Otter aircraft), bipolar research possibilities (e.g., upper atmosphere), and the transfer of arctic expertise (e.g., the value of USAF's basic training on the DEW line) (High Commission, Wellington, 1962c).

\section{SHOULD CANADA ACCEDE TO THE ANTARCTIC TREATY?}

The Antarctic Treaty, signed in December 1959, was ratified by all 12 signatories during 1960-61, and became effective in June 1961. Poland acceded almost immediately. These developments, in conjunction with the manner in which other governments either welcomed Canadian accession as indicating approval of the fundamental principles underlying the treaty (e.g., Australia, Britain) or exchanged views on the subject (e.g., Denmark), reinforced occasional interdepartmental exchanges on the subject. However, the DEA, appreciating governmental unwillingness to become actively involved in Antarctica, remained uncertain about the rights and privileges accruing to acceding states, given the two-tier membership system (Beck, 1986). Exchanges with the British authorities in March 1962 failed to fully clarify the position. Apart from Edmonds, there was little initial enthusiasm for accession, especially because of fears that accession implied acceptance of a similar arrangement for the Arctic. In addition, only treaty parties active in Antarctica (i.e., Consultative Parties) were represented at Antarctic Treaty Consultative meetings, and hence doubts were expressed about Canadian acceptance of the second-class status accorded to acceding states (G. Rowley, pers. comm. 1989). Until the mid-1980s, the latter were not entitled to attend these meetings, even as observers.

One interesting focus for discussion concerned the impact of accession or non-accession upon Canada's continued access to Antarctic research data. The DEA submitted the scientific question to the Advisory Committee on Northern Development (ACND), an active body at this period and very influential on policy (Sicotte, 1961; Rowley, 1992). On 18 December 1961 the ACND, guided by a report from its Scientific Research subcommittee, concluded that the scientific benefits of accession probably outweighed the disadvantages (Rowley, 1992; Rowley, pers. comm. 1993). Rowley, its Secretary, read out the conclusions over the phone to the DEA, whose views were circulated to Canadian missions in Canberra, London, Washington, and Wellington on 27 December 1961 (Robertson, 1961). For the DEA, political and legal considerations held sway over scientific factors.

On balance, it would seem inadvisable at this stage, from a purely political point of view, to accede to the treaty ... the possible political disadvantages might be offset by the possible scientific benefits through our obtaining access to the results of the research being done in the Antarctic (Beesley, 1962).

The ACND's identification of the "considerable assistance" of Antarctic data to Canada's Arctic research programme led to further enquiries about the availability of relevant research reports to non-signatories. In the event, the resulting preparedness of Australia, Britain, New Zealand, and the United States to supply Antarctic data, their willingness to cooperate in bipolar research projects, and the ability of Canadian scientists to work in Antarctica, qualified the force of the ACND's scientific rationale for accession.

On 25 August 1962 a meeting held at the DEA, having considered the general pros and cons of accession, reaffirmed somewhat predictably that the advantages of accession were "not as strong" as often thought (DEA, 1962b). Significantly, this meeting's minutes, like those of the ACND meeting held on this topic during the previous December and several Arctic sovereignty files, remain closed in the archives. Also, as noted by Rowley (1992), severe financial restraints restricted not only the level of activity in the North but also the scope for new initiatives towards the southern polar region, even if Graham Rowley (1966) and Trevor Lloyd (1969-70), among others, remained sympathetic to Canadian participation in Antarctic research networks, like SCAR (Scientific Committee for Antarctic Research).

\section{CONCLUSION: \\ TAKING A CANADIAN POSITION ON ANTARCTICA}

In summer 1948 the Toronto Star (27 August 1948) enquired how interested the Canadian government was in Antarctica. No public response was offered, but the true answer was not very interested. In practice, Antarctica, though difficult to ignore because of its importance to Commonwealth partners, the United States, Argentina and Chile, was treated in Ottawa as "a very marginal topic" (Robertson, 1957).

Although the evolving nature of the Antarctic scene imparted a certain fluidity, the chief elements of policy were in place by August 1948, when St. Laurent, the Minister of External Affairs, decided that Canada should "take no active part" in Antarctica matters (Wardroper, 1948). Henceforth, the government consciously and consistently steered clear of any meaningful involvement in Antarctica. The practical consequences of this decision were illustrated in November 1948; thus, a British request for comment about a draft Anglo-Argentine-Chilean naval agreement on Antarctica elicited a response, agreed to by the minister, "that we have no comment to make on the text of the draft declaration" (DEA, 1948). One decade later, when the Antarctic Treaty negotiations concentrated Canadian minds again, the March 1958 DEA Summary Report confirmed the government's "indirect interest," and largely replicated the points identified in 1948, except that western anxieties about the emerging role of the 
USSR in the region were now taken into account (DEA, 1958). The key element of continuity concerned the perception of Antarctica through Arctic eyes, including the consequent stress upon the distinctiveness of the two polar regions. Canadian politicians and officials, albeit acknowledging their polar character, reiterated constantly the fundamental geographical, political and legal separation of the Arctic and Antarctica. In this vein, during April 1962 the DEA, noting the 1959 Antarctic Treaty, advised a member of parliament on a response to a student query about the polar regions:

You might wish to point out ... that the dissimilarities, both political and physical, between the Arctic and the Antarctic make it inappropriate to equate the two ... Some of the physical dissimilarities are that the Polar Basin of the Arctic is mainly an ocean area, surrounded by continents, whereas Antarctica is a high ice-covered land bounded by the sea ... the Antarctic is the subject of an international treaty whereas the Arctic is not (Robertson, 1962).

The 1959 Antarctic Treaty transformed the south polar scene, but not Canadian policy towards the area. In the event, Canada, having been kept in closer touch with Antarctic affairs since the 1930s than any other government outside the ranks of the Antarctic Treaty's initial twelve signatories, adopted a rather distant attitude on the subject. The government did not accede to the treaty until 4 May 1988, when Joe Clark, Secretary of State for External Affairs, claimed that "Canada, as a leading Arctic state and a major player in polar science and technology, was taking its place among countries with a strong interest in Antarctic matters" (DEA, 1988:1; Beck, 1990). Significantly, Clark, building upon Canada's constant stress upon the region's special character (UN-GAR, 1984; Beck, 1990), reaffirmed the "uniqueness of Antarctica" (DEA, 1988:1). In July 1988 Canada acceded to the Convention for the Conservation of Antarctic Marine Living Resources (CCAMLR), and subsequently took up associate membership in SCAR (1993).

During the late 1980s, the Canadian government was participating at last in Antarctic affairs, even if the two-tier membership system meant that accession involved little more than acceptance of the treaty's principles and, an advance on the early 1960s, observer status at consultative meetings. For many, accession, though long anticipated, was overdue not only because individual Canadian scientists and experts had long been involved in the region but also because it came in the wake of accession to the Antarctic Treaty by 25 other governments since 1961. Even worse, Canada was the last major arctic state to join the Antarctic Treaty System.

Rothwell (1994:72) has suggested that "workable solutions to the legal and political issues confronting the Arctic may be gained by critically assessing the "Antarctic experience'." This article establishes that, at least during the period between 1945 and 1962, Antarctic experience represented one input to Canadian thinking and policy-making about the Arctic, even if the Arctic provided the fundamental framework within which south polar questions were always viewed from Canada. This study offers also a meaningful background for the recent enhancement of Canada's involvement in Antarctic affairs, while performing a prominent role in the cooperative arrangements for the Arctic centred upon the International Arctic Science Committee. Recently, Graham Rowley (pers. comm. 1993), looking back three decades to the period when he was Secretary of the Advisory Committee on Northern Development, commented: "At first I was surprised that there is so little interest in the Antarctic, but Canada has so much Arctic to be concerned with that the Antarctic has to take a very far back seat." For this reason, arctic concerns will remain paramount for Canada.

\section{ACKNOWLEDGEMENTS}

Research conducted in Canada during 1993-94 for this paper was made possible by a Canadian Studies Research Award administered by the Canadian High Commission in London. Relevant material consulted in American, Australian, and British archives for other projects has been incorporated into this study.

\section{REFERENCES}

Note: References from NAC are available at National Archives of Canada, 395 Wellington Street, Ottawa, Ontario K1A 0N3, Canada.

AFONIN, M. 1948. The struggle over the Antarctic. Izvestiya 19 March.

AUSTRALIAN HIGH COMMISSION, DELHI. 1956. Despatch to DEA, Canberra, 19 October 1956, CRS A1838/2, 1495/24/1, Part 1, Australian Archives. The Australian Archives, Cnr. Sandford Street \& Flemington Road, Mitchell, ACT 2911, Australia.

AUSTRALIAN HIGHCOMMISSION, OTTAWA. 1956. Despatch to DEA, Canberra, 7 March 1956, CRS A1838/2, 1495/24/1, Part 1, Australian Archives.

BECK, P.J. 1986. Antarctica in international politics. Beckenham: Croom Helm.

1987. A cold war: Britain, Argentina and Antarctica. History Today 37(6):16-23.

— 1990. Canada as a bi-polar power: Canada's Antarctic dimension. Lakehead Centre for Northern Studies Occasional Paper 7:1-50.

- 1992. Why Study Antarctica? Kingston upon Thames: Apex Centre, Kingston University.

1994. Who owns Antarctica? Boundary and Territory Briefing (1):1-55.

BEEBY, D. 1994. In a crystal land: Canadian explorers in Antarctica. Toronto: University of Toronto Press.

BEESLEY, J.A. 1962. Note to Cadieux, 18 January 1962, RG25 90-91/008, Vol. 200, 50070-40, Part 10, NAC.

BÉRIAULT, Y. 1942. Les problèmes politiques du nord Canadien. Montreal: Bernard Valiquette, and Ottawa: Université d'Ottawa.

BLANCHETTE, A. 1948a. Note to Lloyd, 16 January 1948, RG25 84-85/019, Vol. 3843, 9092-A40 Part 2, NAC. 
. 1948b. Memorandum, 30 March 1948, 50070-40, Vol. 1, NAC.

—. 1948c. Minute, n/d (February 1948), 50070-40, Vol. 1, NAC.

CADIEUX, M. 1956. Note to Under-Secretary, DEA, 28 March 1956, RG25 90-91/008, Vol. 199, 50070-40, Part 4, NAC.

CANADIAN EMBASSY, MOSCOW. 1951. Despatch to DEA, 22 June 1951, RG25 90-91/008, Vol. 199, 50070-40, Part 2, NAC.

CHAPUT, R. 1944. Memorandum for Legal Adviser, DEA, 31 May 1944, 9057 40C, NAC. This file was consulted at the DEA's Historical Division in 1983, but parts of the file are currently closed at the NAC.

CLIFFORD, M. 1950. Report, Polar Committee Paper (50) 11, 8 August 1950, 9092-A40C, Vol. 4, NAC.

COMMONWEALTH RELATIONS OFFICE. 1954. Note to High Commission, London, 28 June 1954, RG25 84-85/150, Vol. 116, 9092-A40, Part 6, NAC.

CORY, T.L. 1936. Memorandum for Northwest Territories Council, 3 June 1936, RG25 G1 Vol. 1422/417C, NAC.

CÔTÉ, E. 1954a. Note, 12 October 1954, RG25 90-91/008, Vol. 199, 50070-40, Part 3, NAC.

_ 1954b. Note to Beaudry, 4 September 1954, RG25 90-91/ 008, Vol. 199, 50070-40, Part 3, NAC.

DAVIES, G. 1994. Obituary: Andrew Taylor. Polar Record 30(173):153-154.

DEA (Department of External Affairs). 1945. Memorandum by Legal Division, 18 October 1945, 50070-40, Vol. 1, NAC.

—. 1948. Memorandum, 29 November 1948, RG25 90-91/ 008, Vol. 199, 50070-40, Part 2, NAC.

- 1955a. Note by Legal Division to Department of Defence, 10 June 1955, RG25 84-85/150, Vol. 116, 9091-40 Part 2, NAC.

- 1955b. Note by Commonwealth Division, 19 September 1955, RG25 90-91/008, Vol. 199, 50070-40, Part 3, NAC.

- 1958. Summary Reports 1958, no.18, 7 March 1958, RG25 90-91/008, Vol. 199, 50070-40, Part 5, NAC.

- 1959a. Note to High Commissioner, Canberra, 16 September 1959, RG25 90-91/008, Vol. 199, 50070-40, Part 7, NAC. - 1959b. Memorandum, 2 December 1959, RG25 90-91/ 008, Vol. 199, 50070-40, Part 8, NAC.

- 1959c. Conference on the Antarctic. External Affairs XI(11):350-351.

1960. A Treaty for Antarctica. External Affairs XII(2): $514-515$.

- 1961. Despatch to High Commission, Wellington, 1 November 1961, RG25 90-91/008, Vol. 199, 50070-40, Part 9, NAC.

- 1962a. Antarctica. External Affairs XIV(5):167-173. 1962b. Despatch to Pick, 14 September 1962, RG25 9091/008, Vol. 200, 50070-40, Part 10, NAC.

. 1985. Competitiveness and security: Directions for Canada's international relations. Ottawa: Department of External Affairs.

- 1988. Press Release, 4 May.

DOMINIONS OFFICE. 1945. Memorandum, April 1945, encl. 9092-A40C, Vol. 1, NAC.

EDMONDS, R. 1962. Note to DEA, 18 January 1962, RG25 90-91/ 008, Vol. 200, 50070-40, Part 10, NAC.
FITZMAURICE, G. 1937. Minute, 27 May 1937, FO371/21231, W10306/1365/50, British Foreign Office (FO) archives, Public Record Office, Kew, Surrey TW9 4DU, England.

GIAEVER, J. 1954. The white desert. London: Chatto and Windus.

GRANT, S.D. 1988. Sovereignty or security? Government policy in the Canadian North, 1936-1950. Vancouver: University of British Columbia Press.

HARDY, G.E. 1959a. Note to Cleveland, 22 December 1959, RG25 90-91/008, Vol. 199, 50070-40, Part 8, NAC.

- 1959b. Memorandum, 11 June 1959, RG25 90-91/008, Vol. 199, 50070-40, Part 7, NAC.

HATTERSLEY-SMITH, G. 1986. Some Canadians in the Antarctic. Arctic 39(4):368-369.

HIGH COMMISSION, WELLINGTON. 1960. Despatch to DEA, 2 November 1960, RG25 90-91/008, Vol. 199, 50070-40, Part 8 , NAC.

. 1961. Despatches to DEA, 13 and 14 November 1961, RG25 90-91/008, Vol. 199, 50070-40, Part 9, NAC.

-. 1962a. Despatch to DEA, 11 January 1962, RG25 90-91/ 008, Vol. 200, 50070-40, Part 10, NAC.

. 1962b. Despatch to DEA, 29 January 1962, RG25 90-91/

008, Vol. 200, 50070-40, Part 10, NAC.

. 1962c. Despatch to DEA, 9 March 1962, RG25 90-91/008, Vol. 200, 50070-40, Part 10, NAC.

HOLMES, J.W. 1979. The shaping of peace: Canada and the search for world order 1943-1957. Vol. 1. Toronto: University of Toronto Press.

IMPERIAL CONFERENCE. 1937. Minutes of Committee on Polar Questions, First Meeting, 26 May 1937, Paper E(37), RG25 G1, Vol. 1789/318Q, NAC.

KILLAS, M. 1987. The legality of the Canadian claim to the waters of its arctic archipelago. Ottawa Law Review 19(1):95-136.

KOSTRITSYN, B.V. 1951. Regarding the question of the regime of the Antarctic. The Soviet State and Law 3:38-43.

LÉGER, J. 1957. Despatch to High Commission, London, 20 June 1957, RG25 90-91/008, Vol. 199, 50070-40, Part 4, NAC.

LEONTIEV, B. 1950. On the question of the regime of the Antarctic. Pravda 20 July.

LLOYD, T. 1947. Note to Department of Mines, 19 December 1947, RG25 84-85/019, Vol. 265, 9091-40 Part 1, NAC.

- 1948. Note to Blanchette, 18 February 1948, 50070-40, Vol. 1, NAC.

1969-70. Some international aspects of Arctic Canada. International Journal 25:717-725.

MARSDEN, M. 1966. Resources and communications in the Arctic. In: MacDonald, R. St. J., ed. The Arctic frontier. Toronto: Canadian Institute of International Affairs and Arctic Institute of North America/University of Toronto Press. 26-56.

MITCHELL, R. 1950. Despatch to State Department, 24 January 1950, RG59, Box 3066, 702.022/1-2450, US State Department Files, US National Archives, Washington D.C. 20408, U.S.A. In Spring 1995 the State Department archives are being moved to Archives II, College Park, Maryland, U.S.A.

MOLSON, P. 1948. Memorandum, 16 January 1948, encl. 9092A40, Vol. 2, NAC.

PARRY, J. 1954. Note to American Division, 7 September 1954, RG25 90-91/008, Vol. 199, 50070-40, Part 3, NAC. 
PEARSON, L.B. 1945-46. Canada looks “down north.” Foreign Affairs XXIV(4):638-647. . 1948. Memorandum, 30 July 1948, 50070-40, Vol. 1, NAC. . 1953. Note, n/d (February 1953), RG25 90-91/008, Vol. 199, 50070-40, Part 3, NAC.

. 1955. Memorandum, 12 September 1955, RG25 84-85/ 019, Vol. 265, 9091-40, Part 1, NAC.

PHARAND, D. 1988. Canadian Arctic waters in international law. Cambridge: Cambridge University Press.

PRESTON, R.A. ed. 1965. Canada in world affairs, Vol. XI, 195961. Toronto: Oxford University Press/Canadian Institute of International Affairs.

PYMAN, D. 1956. Australian High Commission, Ottawa, to DEA, Canberra, 24 February 1956, A1838/2, 1495/24/1, Part 1, Australian Archives.

ROBERTSON, N. 1957. Despatch to DEA, 22 March 1957, RG25 90-91/008, Vol. 199, 50070-40, Part 4, NAC.

1961. Note, 27 December 1961, RG25 90-91/008, Vol. 199, 50070-40, Part 9, NAC.

- 1962. Letter to A. Macnaughton, MP, 11 April 1962, RG 25 90-91/008, Vol. 200, 50070-40, Part 10, NAC.

ROOTS, E.F. 1987. Canada and polar science. Ottawa: Department of Indian Affairs and Northern Development.

ROSE, D.C. 1957. Paper, n/d (June 1957), RG25 84-85/215, Vol. 42, 12320-40 Part 1, NAC.

ROTHWELL, D.R. 1994. Polar lessons for an Arctic regime. Cooperation and Conflict 29(1):55-76.

ROWLEY, G.W. 1966. International scientific relations in the Arctic. In: MacDonald, R. St. J., ed. The Arctic frontier. Toronto: Canadian Institute of International Affairs and Arctic Institute of North America/University of Toronto Press. 279-292.
1992. The role of the Advisory Committee on Northern Development in the development of policy and the coordination of federal government activities in northern Canada. Ottawa: Circumpolar and Scientific Affairs, Department of Indian Affairs and Northern Development.

SICOTTE, G. 1961. Note to Under-Secretary of State, DEA, 28 June 1961, RG25 90-91/008, Vol. 199, 50070-40, Part 9. This note is closed in NAC.

SOLEM, E., and GREENAWAY, K. 1989. Canada as a circumpolar nation. In: Painchaud, P., ed. From Mackenzie King to Pierre Trudeau: Forty years of Canadian diplomacy 1945-1985. Quebec: Les presses de l'université Laval. 447-468.

SOUTH AFRICAN DEA (South African Department of External Affairs). 1948. Note to DEA, Canada, 19 February 1948, 5007040, Vol. 1, NAC.

TAYLOR, A. 1947. Two years in the Antarctic. Unpubl. ms. not approved by government for publication, AD6/15/1, British Antarctic Survey Archives, High Cross, Madingley Road, Cambridge CB3 0ET, England.

UN-GAR (United Nations General Assembly Records). 1984. Canadian note to United Nations, 5 July, Document A39/583, Part II, Vol. 2.

UNITED STATES GOVERNMENT. 1952. Position Paper, 15 July 1952, RG59, Box 3061, 702.022/7-1552, US State Department Files, US National Archives, Washington D.C. 20408, U.S.A.

WARDROPER, K.W. 1948. Note, 25 October 1948, RG25 90-91/ 008, Vol. 199, 50070-40, Part 2, NAC.

WILSON, J.T. 1958. Quoted, High Commission, Wellington to DEA, 5 December 1958, RG25 86-87/414, Vol. 162, 12320-40, Part 2, NAC.

WRONG, H. 1946. Despatch to Pearson, 30 December 1946, 50070-40, Vol. 1, NAC. 